\title{
ФУНКЦІОНАЛЬНИЙ ПІДХІД ДО УПРАВЛІННЯ У СИСТЕМІ МІСЦЕВОГО САМОВРЯДУВАННЯ В УКРАЇ̈Н
}

\section{FUNCTIONAL APPROACH TO GOVERNANCE IN THE SYSTEM OF LOCAL GOVERNMENT IN UKRAINE}

\author{
Данилевич Наталія Михайлівна \\ кандидат економічних наук, доцент, \\ Львівський національний університет імені Івана Франка \\ ORCID: https://orcid.org/0000-0001-9906-1492
}

Danylevych Nataliia

Ivan Franko National University of Lviv

\begin{abstract}
Стаття присвячена актуальним питанням застосування функціонального підходу до управління в системі місцевого самоврядування в Україні. Досліджено світовий досвід управління в системі місцевого самоврядування та вивчено організацію діяльності системи місцевого самоврядування, узагальнено теоретико-методологічної основи фрункціонального підходу до управління. Практична значущість статті полягає в тому, що на базі аналізу широкого масиву джерел узагальнено і наведено характеристику організації роботи фрункціонального підходу до управління в системі місцевого самоврядування, сформульовані рекомендації для реорганізації системи місцевого самоврядування в Україні. Наукова новизна одержаних результатів полягає в комплексному аналізі та розробці наукових положень функціонального підходу до управління в системі місцевого самоврядування та моделюванні перспектив розвитку системи управління в сучасній Україні.

Ключові слова: управління, фрункціональний підхід, місцеве самоврядування, державне управління, організаційна структура.

Статья посвящена актуальным вопросам применения функционального подхода к управлению в системе местного самоуправления в Украине. Исследована мировой опыт управления в системе местного самоуправления и изучено организации деятельности системы местного самоуправления, обобщенно теоретико-методологической основы функционального подхода к управлению. Практическая значимость статьи заключается в том, что на основе анализа широкого массива источников обобщенно и приведена характеристика организации работы фрункционального подхода к управлению в системе местного самоуправления, сфрормулированы рекомендации по реорганизации системы местного самоуправления в Украине. Научная новизна исследования заключается в комплексном анализе и разработке научных положений функционального подхода к управлению в системе местного самоуправления и моделировании перспектив развития системы управления в современной Украине.
\end{abstract}

Ключевые слова: управление, ффункциональный подход, местное самоуправление, государственное управление, организационная структура

The purpose of this article is to study topical issues of application of a functional approach to governance in the system of local self-government in Ukraine. The organization of activity of the system of local self-government is studied, the theoretical and methodological basis of the functional approach to management is generalized. Realization of the set purpose is reached by statement and realization of the following tasks: definition of essence of the functional approach to management of the organization the analysis of application of the functional approach to management of the organization is carried out, the characteristic of the functional approach to management in system of local government in Ukraine is given. self-government in Ukraine. In the course of the research general scientific methods, methods of comparisons, groupings, observations, questionnaires, SWOT-analysis were used. The method of comparison allowed to distinguish the similarities and differences of the studied objects, theories and characteristics. The grouping method allowed to develop primary analytical material. The method of observation revealed external signs and external manifestations of the facts of the object under study. The method of questionnaires allowed to get a complete picture of public opinion on the problems, needs and interests. SWOT-analysis - a method used to assess the strengths and weaknesses of the organization, as well as to assess the opportunities and threats affecting it. The scientific novelty of the obtained results lies in the complex analysis and development of scientific provisions of the functional approach to management in the system of local self-government and modeling 
of prospects of development of the management system in modern Ukraine. The practical significance is that on the basis of the analysis of a wide array of sources the characteristic of the organization of work of the functional approach to management in system of local government is generalized and resulted, recommendations for reorganization of system of local government in Ukraine are formulated.

Keywords: management, functional approach, local self-government, public administration, organizational structure.

Постановка проблеми. Актуальність теми дослідження зумовлена тим, що всі наукові дослідження вказують на те, що без ефрективної організаційної структури організації неможливе її економічне зростання. Станом на сьогодні існує багато наукових підходів до управління, але будь-яка організація являє собою певну цілісність, що складається 3 структурних підрозділів, які в свою чергу, знаходяться у субординаційних ієрархічних відносинах, де управління здійснюється на вищому щаблі.

Отож, саме фрункціональний підхід до управління $\epsilon$ домінуючим методом наукового підходу. Суть фрункціонального підходу до управління полягає в тому, що будь-яка потреба розглядається як сукупність певних фрункцій, які необхідно виконати. За допомогою функціонального підходу можливо вирізнити основну сукупність фрункцій та їх систематизацію. В даному випадку сукупність фрункцій організації має ієрархічний характер.

Появу та розвиток фрункціонального підходу зумовило дослідження різних об'єктів, їх фрункціонування та зв'язки із зовнішнім середовищем. Даний підхід в управлінні підприємством дає змогу повніше аналізувати природу ієрархічних об'єктів, розрізнити цілісні та організовані системи серед усіх інших об'єктів та їхніх сукупностей.

Динаміка зовнішньополітичного курсу України на європейську інтеграцію зумовлене зацікавленістю 3 боку європейського товариства, відкритості для вступу нових членів до ЄС. Більшість законодавчих та нормативно-правових актів України не відповідають вимогам єдиного адміністративного простору Європи. Це стосується і органів виконавчої влади та місцевого самоврядування, зауважимо, що деякі з них неефективно виконують свої фуннції. Існуюча система місцевого самоврядування в Україні станом на сьогодні не задовольняє потреб населення. У більшості територіальних громад нашої країни, діяльність місцевого самоврядування має низку проблем, але основна 3 них це не належне забезпечення, створення та підтримка сприятливого середовища для життя громадян, захисту їх прав. Окрім цього для якісного життя громадян, важливо створити систему надання якісних та доступних адміністративних та соціальних послуг, за допомогою сталого розвитку громади, надання можливостей для її всебічного розвитку. Саме це створює передумови для ресрормування діяльності органів місцевого самоврядування.

Проблема оптимізація структури управління органів місцевого самоврядування $€$ актуальною в нашій країні. Суть проблеми -у відсутності необхідної координації діяльності органів місцевого самоврядування. Варто зауважити, що обмеженість у ресурсному та кадровому забезпеченні діяльності органів місцевого самоврядування, невизначеність місця та значення цих органів у процесах євроінтеграції, всі ці фрактори негативно впливають на оптимізацію системи управління місцевого самоврядування.

Аналіз основних досліджень і публікацій. Інфрормаційною базою $є$ праці українських і закордонних фрахівців в області менеджменту; матеріали наукових конференцій; періодичної преси. Функціональний зміст управління висвітлили в своїх працях закордонні науковці, а саме: М. Альберт, Ф. Тейлор, Г. Черч, Л. Джильберт, М. Мескон, Ф. Хедоурі, А. Файоль. Значну увагу цьому питанню приділили і вітчизняні науковці Г. Таукач, М. Мартиненко, В. Голіков, О. Кузьмін, В. Герасимчук, Ф. Хміль, Г. Попов, О. Козлова, Г. Одінцова, Б. Смірнов, 3. Румянцева, О. Бобров, Б. Мізюк, В. Геєць та інші науковці 3 питань управління організацією.

Виділення невирішених раніше частин загальної проблеми полягає у закцентовано увагу на можливості застосування фрункціонального підходу до управління в системі місцевого самоврядування в Україні.

Метою статті $\epsilon$ вивчення організаційної діяльності системи місцевого самоврядування, узагальнення теоретико-методологічної основи фрункціонального підходу до управління.

Реалізація поставленої мети досягається шляхом постановки наступних завдань: визначення сутність фрункціонального підходу до управління в системі місцевого самоврядування; аналіз застосування функціонального підходу до управління в системі місцевого самоврядування; характеристика фрункціо- 
нального підходу до управління в системі місцевого самоврядування; шляхи вдосконалення фрункціонального підходу до управління в системі місцевого самоврядування.

Виклад основного матеріалу. Державне управління універсальне явище, яке притаманне всім без винятку країнам. Воно проявляється в практичній діяльності державних органів 3 реалізації політики держави та забезпечення його інтересів. Державне управління спрямоване на поліпшення використання природних, матеріальних, трудових ресурсів, управління галузями народного господарства і соціальної ссрерою, охорони прав громадського порядку і захист законних інтересів громадян. В даному процесі виконуються фрункції організації, координації, планування, контролю, аналізу та інші; застосовуються таких методи як стимулювання, переконання, покарання та примусу.

Державне управління охоплює три гілки влади - законодавчу, виконавчу і судову, а також їхній взаємозв'язок.

- Законодавча влада - це делегована народом своїми представникам у парламенті державна влада, що має виключне право приймати закони. Органом законодавчої влади є парламент держави, відповідно до ст. 75 Конституції України «єдиним органом законодавчої влади в Україні $\epsilon-$ Верховна Рада України»;

- Виконавча влада - це система органів, які спеціально створюються державою для виконання фрункцій управління й забезпечення нормального фрункціонування державної влади та суспільства шляхом реалізації нормативно-правових актів. Органами виконавчої влади в Україні - $є$ система центральних і місцевих, одноособових і колегіальних, органів виконавчої влади загальної та спеціальної компетенції на чолі з Кабінетом Міністрів України, що відповідно до Конституції та законів України забезпечують виконання Конституції України, законів України, постанов Верховної Ради України та указів Президента України в найважливіших сорерах державного і суспільного життя України [1, с. 101-103];

- Судова влада - це діяльність всіх створених у державі судів, яка реалізується з допомогою притаманних їм і законодавчих засобів 3 метою впливу на поведінку суб'єктів права та суспільні відносини за участю цих суб'єктів [2, c. 24].

Державне управління - система, яка постійно розвивається, вона охоплює декілька рівнів: загальнодержавне управління, управління на регіональному та місцевому рівнях.
В системі органів виконавчої влади виділяються структурні ланки трьох організаційноправових рівнів, які складають ієрархічну вертикаль:

- вищий рівень - Кабінет Міністрів України (у срункціональній взаємодії з Президентом України);

- центральний рівень - міністерства, державні комітети та інші підвідомчі Кабінету Міністрів України органи виконавчої влади;

- місцевий, або територіальний рівень, на якому діють: органи виконавчої влади загальної компетенції;

- органи спеціальної галузевої та фрункціональної компетенції, які як безпосередньо підпорядковані центральним органам виконавчої влади, які так і перебувають у так званому подвійному підпорядкуванні [3, с. 263-264].

Всі фрункції державного управління здійснюється через певний комплекс управлінських фрункцій цих органів, які розподілені по «вертикалі» та «горизонталі».

Формування організаційної структури державного управління базується на фрункціональній структурі, яка залежить від сукупності управлінських фрункцій, які повинні бути реалізовані владними структурами на різних рівнях державно-управлінської системи.

За умов інтенсивних демократичних, соціальних, державно-правових перетворень, що відбуваються сьогодні в Україні, істотно змінюється роль місцевого самоврядування, його повноваження, фрункції. Розбудова сучасної, демократичної , правової та соціальної держави, яку проголошує Конституція України, можлива через розбудову інституту місцевого самоврядування [4, с. 75].

Під системою місцевого самоврядування розуміють сукупність організаційно-правових форм та інститутів місцевого самоврядування, його суб'єктів, завдяки яким населення територіальної громади вирішує місцеві проблеми, реалізує надані йому функції та повноваження, це певна модель здійснення публічної влади на місцевому рівні.

Отож, місцеве самоврядування в Україні це гарантоване державою право та реальна здатність територіальної громади - жителів села чи добровільного об'єднання в сільську громаду жителів кількох сіл, селища, міста самостійно або під відповідальність органів та посадових осіб місцевого самоврядування вирішувати питання місцевого значення в межах Конституції і законів України.

Визначення поняття системи місцевого самоврядування $є$ складним 3 боку законо- 
давства. Згідно статті 5 Закону України «Про місцеве самоврядування в Україні» випливає, що до системи місцевого самоврядування входять: територіальна громада; сільська, селищна, міська рада; сільський, селищний, міський голова; виконавчі органи сільської, селищної, міської ради; староста; районні, обласні ради; органи самоорганізації населення (рис. 1).

В структурно-організаційному плані, система місцевого самоврядування являє собою сукупність органів місцевого самоврядування, органів самоорганізації населення та організаційних форм, за допомогою яких відповідна територіальна громада або її складові частини здійснюють завдання та фрункції місцевого самоврядування, вирішують питання місцевого значення.

Територіальні громади $€$ первинними об'єктами місцевого самоврядування. Це жителі, які об'єднані постійним місцем проживання у межах міста, селища, села, що є самостійною територіально-адміністративною одиницею. Місцеве самоврядування здійснює свою діяльність через територіальні громади сіл, селищ, міст як безпосередньо, так і через сільські, селищні, міські ради та їх виконавчі органи, а також через районні та обласні ради, які представляють спільні інтереси територіальних громад сіл, селищ, міст.

Місцеве самоврядування виступає одним із найважливіших принципів організації та фрунк- ціонування влади в суспільстві, тай в державі в цілому, і $є$ важливим атрибутом будь-якого демократичного ладу.

За своєю природою, місцеве самоврядування виступає як характерна фрорма реалізації публічної влади, воно втілює місцеві інтереси та потреби територіальних громад та $€$ однією з фрорм залучення громадян України до участі в управлінні держави [5, с. 141].

Отож, місцеве самоврядування, як специфрічна фрорма реалізації належної народові влади характеризується:

1) місцеве самоврядування має особливого об'єкта - територіальну громаду, тобто жителів села чи добровільного об'єднання у сільську громаду жителів кількох сіл, селища та міста. Повноваження територіальна громада здійснює безпосередньо та через органи місцевого самоврядування;

2) в механізмі управління суспільством та державою система місцевого самоврядування займає окреме місце. Згідно Конституції України, органи місцевого самоврядування, не входять до механізму державної влади, але це не означає його повної автономності від держави та державної влади.

Цілі та завдання, що стоять перед органами місцевого самоврядування, визначають основні фрункції цих органів. Проаналізувавши вищевказане, умовно, фрункції управління місцевого самоврядування, можна розділити на такі групи:

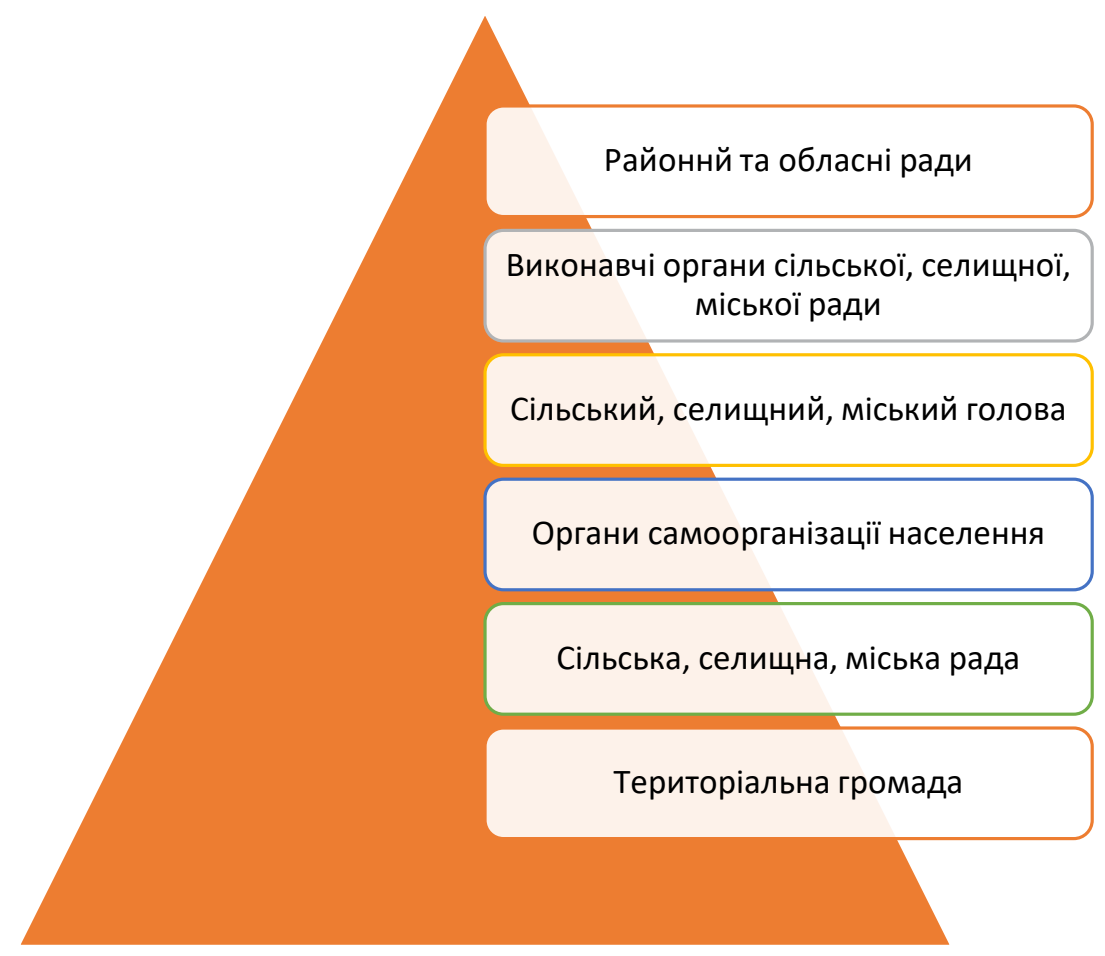

Рис. 1. Система місцевого самоврядування в Україні 
- управлінські;

- господарсько-економічні;

- соціально-демографрічні;

- соціально-культурні.

Зазначимо, що кожна 3 цих груп містить фрункції управління конкретною галуззю господарства.

Відомо, що основною метою місцевого самоврядування $€$ задоволення місцевих потреб і вирішення проблем, що виникають на певній території.

Система фуннццій місцевого самоврядування накладається, відповідно, на цикли здійснення будь-якого управлінського процесу або механізму управлінської технології, у його структурі якої можна виділити кілька етапів, а саме:

- формування цілей (поєднує в себе аналіз ситуації, вияв проблеми та визначення конкретних завдань щодо її уникнення);

- прийняття рішень (розробка системи можливих дій і вибір оптимального варіанта);

- організація діяльності (розподіл завдань та повноважень, координація та контроль процесу виконання);

- формування висновків та підсумків, аналіз результатів.

Функції та повноваження місцевих органів самоврядування ґрунтуються на принципах галузевої компетенції, яку можна поділити на три різновиди:

- виключна компетенція місцевих державних адміністрацій (для прикладу, державний контроль);

- суміжна компетенція, коли місцеві державні адміністрації і органи місцевого самоврядування наділяються повноваженнями в одній галузі суспільного життя;

- виключна компетенція органів місцевого самоврядування (для прикладу, управління комунальною власністю).

Функції місцевого самоврядування мають юридично закріплену основу в Законі Україні «Про місцеві самоврядування в Україні» у вигляді предметів відання органів місцевого самоврядування.

Для кращого розуміння суті фрункціонального підходу в системі місцевого самоврядування, варто систематизувати фрункції, які виконують органи муніципальної влади.

За фрормами діяльності виділяють:

- нормотворчу фрункцію;

- установчу фрункцію;

- контрольну функцію;

- правоохоронну фрункцію.

За сферами діяльності розмежовують наступні фрункції:
- забезпечення комплексного розвитку території громади;

- планування;

- бюджетно-срінансову;

- управління комунальною власністю й місцевими фрінансами;

- забезпечення потреб населення у житлових, транспортних, комунально-побутових послугах;

- соціального захисту населення;

- зовнішньоекономічну;

- розвитку охорони здоров'я, освіти, культури та спорту;

- природоохоронну;

- регулювання земельних відносин;

- інфрормаційну та дозвільно-реєстраційну.

Зв'язок між загальними та конкретними срункціями є дуже важливим. А саме тому, що будь-яка конкретна фрункція повинна виконуватись за допомогою застосування загальних фуннкцій, тобто, загальні функції є інструментом для виконання конкретних. Причому дуже важливою умовою $є$ те, що потрібно виконувати всі фрункції, без винятку, адже погане виконання або його цілковите незастосування хоча би однієї з них може призвести до недосягнення очікуваних результатів, а деколи навіть до негативних наслідків. Тому для розгляду управління місцевого самоврядування потрібно детально зупинитися на загальних срункціях управління.

Для прикладу, реалізація нормотворчої срункції полягає в здійснені правового регулювання муніципальних відносин в межах своїх повноважень. Це порядок управління та розпорядження комунальною власністю, місцевими ресурсами, регулювання земельних відносин, використання об'єктів місцевого значення. Окрім цього, здійснення нормотворчої фрункції проявляється в розробці та прийнятті статусу територіальних громад, регламенту відповідної ради, затвердженні положення про громадські слухання, місцеві ініціативи, прийнятті нормативних актів локального характеру.

Суть правоохоронної фрункції складає охорона громадського порядку, що $є$ важливою умовою підтримання на території громади законності, забезпечення діяльності та контролю всієї системи правоохоронних та судових органів.

Реалізовуючи установчу фрункцію, органи місцевого самоврядування на планетарних засіданнях вирішують питання щодо визначення відповідно до закону кількісного складу комісій ради, її виконавчих органів, апарату 
влади та її виконавчих органів, забезпечуючи повну організаційну самостійність місцевого самоврядування.

Щодо суті контрольної фуункції, вона включає в себе здійснення органами місцевого самоврядування численних контрольних заходів для перевірки діяльності посадових осіб [6, с. 97-103].

Звісно ж, основною фрункцією місцевого самоврядування $€$ задоволення потреб населення в житлових, транспортних та комунальнопобутових послугах. Здійснюється це шляхом реалізації органами і посадовими особами повноважень щодо управління об'єктами житлово-комунального господарства, побутового обслуговування, транспорту і зв'язку, що перебувають в комунальній власності відповідних територіальних громад, забезпечення їх належного утримання, ефрективної експлуатації, необхідного рівня та якості послуг населенню, утримання і використання комунального житлового фонду, утримання доріг місцевого значення, організація транспортного обслуговування населення, благоустрою території, утримання комунальних установ охорони здоров'я, освіти, культури та спорту [7, с. 157-159].

Виконуючи фрункцію соціального захисту населення, органи місцевого самоврядування мають повноваження щодо вирішення питань, згідно законодавства, щодо допомоги незахищеним верствам населення.

Отже, зазначимо, що структура механізму реалізації фрункцій місцевого самоврядування значною мірою визначена сутністю та змістом виконуваних фрункцій. Зважаючи на це, саме сутність та зміст функцій місцевого самоврядування детермінують конкретну конорігурацію механізму їх реалізації, елементний склад та принципи взаємодії між цими елементами.

Висновки. Основною фуункцією місцевого самоврядування $€$ задоволення потреб населення в житлових, транспортних та комунально-побутових послугах. Здійснюється це шляхом реалізації органами і посадовими особами повноважень щодо управління об'єктами житлово-комунального господарства, побутового обслуговування, транспорту і зв'язку, що перебувають в комунальній власності відповідних територіальних громад, забезпечення їх належного утримання, ефективної експлуатації, необхідного рівня та якості послуг населенню, утримання і використання комунального житлового фронду, утримання доріг місцевого значення, організація транспортного обслуговування населення, благоустрою території, утримання комунальних установ охорони здоров'я, освіти, культури та спорту.

Функціональний підхід розглядає безпосередньо процес управління організацією як процес в якому діяльність, спрямована на досягнення цілей організації, розглядається не як єдина дія у часі, а як серія безперервних взаємопов'язаних фрункцій управління, пов'язаних послідовно і паралельно: планування, організація, мотивація, контроль, координація, регулювання, прийняття управлінських рішень ці питання будуть досліджуватися на прикладі конкретної селищної ради.

\section{СПИСОК ВИКОРИСТАНИХ ДЖЕРЕЛ:}

1. Мельник А.Ф., Васіна А.Ю., Дудкіна О.П. Державне і регіональне управління : навчальний посібник. Тернопіль : ТНЕУ, 2014. 452 с.

2. Сороко В.М. Оцінка ефективності діяльності державних службовців. Вісник державної служби України. 2006. № 2. C. 20-26.

3. Петришин О.О. Правові засади місцевого самоврядування в зарубіжних країнах та Україні: теоретикоправовий та порівняльний аналіз : монографрія. Харків : Право, 2014. 189 с.

4. Батанов О.В. Муніципальна влада в Україні: проблеми теорії та практики : монограсрія. Київ : Юридична думка, 2010. 656 с.

5. Варналій 3. Регіональна політика України: нові умови, нові вимоги. Стратегічні пріоритети. 2007. № 1(2). С. 141-149.

6. Круш П.В. Регіональне управління : навчальний посібник. Київ : ЦУЛ, 2007. 248 с.

7. Дзюндзюк В.Б. Публічне адміністрування в Україні : навчальний посібник. Харків : Магістр, 2014. 306 с.

\section{REFERENCE:}

1. Meljnyk A.F., Vasina A.Ju., Dudkina O.P. (2014) Derzhavne i reghionaljneupravlinnja [State and regional management]: navchaljnyj posibnyk [a textbook]. Ternopilj: TNEU, 452 p. (in Ukrainian)

2. Soroko V.M. (2006) Ocinka efektyvnosti dijaljnosti derzhavnykh sluzhbovciv [Evaluation of the effectiveness of civil servants]. Visnyk derzhavnoji sluzhby Ukrajiny, no. 2, pp. 20-26. 
3. Petryshyn O.O. (2014) Pravovi zasady miscevogho samovrjaduvannja v zarubizhnykh krajinakh ta Ukrajini: teoretyko pravovyj ta porivnjaljnyj analiz [Legal principles of local self-government in foreign countries and Ukraine: theoretical, legal and comparative analysis]: monoghrafiya [a monograph]. Kharkiv: Pravo, 189 p. (in Ukrainian)

4. Batanov O.V. (2010) Municypaljna vlada v Ukrajini: problemy teoriji ta praktyky [Municipal power in Ukraine: problems of theory and practic]: monoghrafiya [a monograph]. Kyiv: Jurydychna dumka, $656 \mathrm{p}$.

5. Varnalij Z. (2007) Reghionaljna polityka Ukrajiny: novi umovy, novi vymoghy [Ukraine's regional policy: new conditions, new requirements]. Strateghichni priorytety, no. 1(2), pp. 141-149.

6. Krush P.V. (2007) Reghionaljne upravlinnja [Regional management]: navchaljnyj posibnyk [a textbook]. Kyiv: CUL, $248 \mathrm{p}$.

7. Dzjundzjuk V.B. (2014) Publichne administruvannja v Ukrajini [Public administration in Ukraine]: navchaljnyj posibnyk [a textbook] Kharkiv: Maghistr, $306 \mathrm{p}$. 